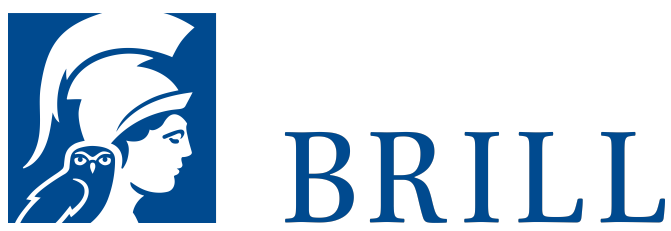

\title{
Vergebliche Zusammenhänge?
}

Erkenntnispolitische Relationierungen von Bildung und Kritik

Author: Richard Kubac

Wie noch sinnvoll über Bildung und Kritik sprechen, wenn beide doch längst zu Allerweltsbegriffen geworden sind, die unterschiedlichste Bedeutungen, Ansprüche und Erwartungen scheinbar fraglos vereinen können? Angesichts der andauernden Legitimationskrise bildungstheoretischer Grundlagenreflexion, die sich in aktuellen Diskurslagen symptomatisch durch eine Inflation und Trivialisierung des Begriffsgebrauchs von Bildung wie auch von Kritik äußert, nimmt der vorliegende Band eine erkenntnispolitische Perspektivierung zeitgenössischer Verhältnisbestimmungen von Bildung und Kritik vor. Es wird aufgezeigt, dass Thematisierungsweisen von Bildung und Kritik in einem bisher häufig vernachlässigten - Verweisungszusammenhang stehen, dessen Berücksichtigung neue Impulse für ein Bildungsdenken abseits tradierter Positionen in Aussicht stellt. Dieser tritt dann deutlich hervor, wenn grundlagenreflexive Theoriearbeit selbst auch als politischer Einsatz innerhalb bildungswissenschaftlicher Erkenntnisbemühungen verstanden wird. Die Bedeutung eines solchen Einsatzes erwächst schließlich daraus, der fortgeschrittenen Bedeutungserosion von Bildung wie auch von Kritik das entgegenzusetzen, was sich in ihrem Namen jeweils der Artikulation entzieht, dem Denken aber dennoch aufgegeben bleibt - stets an den Grenzen des vermeintlich Selbstverständlichen.

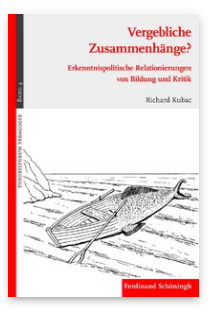

Pages: 216 Seiten, $5 \mathrm{~s} / \mathrm{w}$ Abb.

Language:

German

Subjects:

General,

Education

Publisher: Brill |

Schöningh

Series:

Theorieforum

Pädagogik,

Volume: 4

E-Book (PDF)

Released online: 10 Apr 2013

ISBN: 978-3-

657-7766o-3

Paperback

Publication date: o8 Apr 2013

ISBN: 978-3506-7766o-о List price USD $\$ 52.00$ 
Richard Kubac, Dr. phil., ist Bildungswissenschaftler in Wien.

For more information see brill.com

Order information: Order online at brill.com +44330 3330049 | customerservices@brill.com Submission information: brill.com/authors

Titles published by Brill | Fink, Brill | mentis or Brill | Schöningh: +49(o)71 5413279216 | brill@brocom.de 